
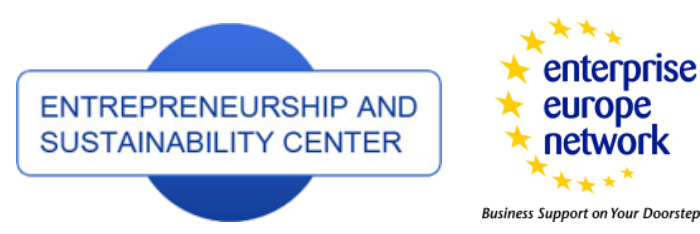

CASPA
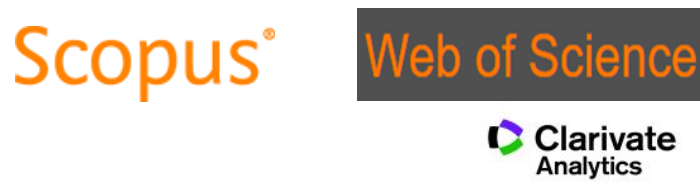

Publisher

http://jssidoi.org/esc/home

\title{
PROBLEMS OF CORRUPTION AND TAX EVASION IN CONSTRUCTION SECTOR IN BELARUS*
}

\author{
Anastasiya Luzgina \\ Belarusian Economic Research and Outreach Center (BEROC) \\ Gazety Pravda Av. 11B, office 4, Minsk 220016, Belarus \\ E-mail: Luzgina@beroc.by
}

Received 25 August 2017; accepted 18 November 2017; published 29 December 2017

\begin{abstract}
Construction sector is on of the most closed and corrupted sector in many countries. Belarus is no exception. For understanding the real situation with corruption and tax evasion in construction sector in Belarus the survey of 50 construction companies was done. According to achieved results, a large share of respondents agreed that some companies of the sector have hidden income, pay salaries "in envelopes" and spend some money for resolving problems with state institutions. At the same time construction enterprises that participated in tenders on municipal procurement underline many problems in this specific sphere. All these problems can be divided by administrative, economic and problems associated with the existence of corruption and the shadow economy. The most popular answers include corruption, unfair competition and imperfect legislation. On the base of international experience and the results of the survey we develop the list of recommendations for decreasing the level of corruption and tax evasion in construction sector that will support to create favorable environment for business development of the country.
\end{abstract}

Keywords: corruption, tax evasion, construction, shadow economy, municipal procurements

Reference to this paper should be made as follows: Luzgina, A. 2017. Problems of corruption and tax evasion in construction sector in Belarus, Entrepreneurship and Sustainability Issues 5(2): 263-282. http://doi.org/10.9770/jesi.2017.5.2(8)

JEL Classifications: H26, H57, H83

\section{Introduction}

The problems of corruption and tax evasion are very relevant for most countries in the world. However, in some states the level of corruption remains very high, while in other countries it is at a rather low level. The size of corruption and tax evasion can be differ not only by country, but also by sector. For example, construction is traditionally an area with a very high risk of corruption and the development of shadow economy. For the countries of the post-Soviet space, the problems of corruption are also very actual. For example, in the Baltic States, there are a number of empirical and research works, which analyse the level of shadow economy in details. At the same time, there are practically no studies on this issue in Belarus. In order to underline the importance of the topic for Belarus we analise the level of shadow economy in the international comparison in the third part of the paper.

\footnotetext{
"This research was written in the framework of the project "Corporate engagement in fighting corruption and tax evasion". The project is financed by Nordic Council of Ministers.
} 
According to our opinion, measures to fight corruption and tax evasion must be developed and approved constantly. However, it is very important to determine the reasons and conditions that provoke the growth of shadow economy. When we understand and know the main problems, it is necessary to develop conditions that will be favourable for the development of legal business and decrease the level of corruption schemes.

The object of the research is the level of corruption and tax evasion in construction sector. Proceeding from this, the main goal of the paper is the development of measures' list for reduction the level of corruption and tax evasion in the construction sector of the Republic of Belarus. The construction sector wasn't accidentally chosen for research. In many countries this sphere of the national economy traditionally are less open and transparent for control. In addition, construction is one of the main sectors of the Belarusian economy.

To understand the problem, a survey in the construction industry was conducted. Enterprises were asked a number of questions that helped to understand the real picture. This survey has been done on the base of the method developed by Talis Putnins and Arnis Sauka. In the framework of this approach we formed the Questionnaire, which includes indirect questions about situation in corruption and tax evasion in construction sector in Belarus. First part of questions supports to understand the current situation in the company and includes such indicators like level of employment, growth (decline) of profit, the average level of salaries in the company and etc. The second part of questions containes information about informal sector, such as: the share of unofficial salaries and employees or the level of hidden income. This part also includes questions about main barriers for business development, quality of national legislation and government support. Last but not the least part of the research supports to understand obstacles in the sphere of public procurements. The companies has been asked about quantity of participants in an average public procurement tender, problems and obstacles of legislation in the sphere.

To process the obtained data, such methods like statistical, graphical, method of grouping, detalization and information summarizing, as well as the method of comperison have been applied. The Survey analysis helped to understand the real situation and underlined the main challenges, which construction companies have placed. The results of the Survey, as well as the analysis of national legislation and international experience allowed to identify main reasons and conditions of the shadow economy in the construction sector of the Republic of Belarus. At the end of the research the list of measures for declining the level of corruption and tax evasion in construction sector of Belarus has been developed.

Publications of Belarusian and foreign authors were used in the paper. Much attention was paid to the research of public procurement procedure. For understanding this issue, the OECD approaches and the experience of Sweden were considered, as well as the national legislative acts of Belarus regulating procurement in construction. Papers of Talis J. Putnis and Arnis Sauka have become a base for conducting and analysing the survey of Belarusian companies in the field of corruption and tax evasion in construction. A lot of information was received from the work "Social Identity cards in the European construction industry", which describes main peculiarities and the positive effect of introducing identity cards in construction in European countries. The paper of Litina, A. and Palivos, T. "Corruption and tax evasion: reflections on Greek tradegy", as well as paper of Schneider F. and Williams C.C. "The shadow economies" could understand the issue of shadow economy in more details. The paper of Igor Pelipas and Irina Tochitskaya was very important for our research because it assess the corruption from the small and medium-sized enterprises point of view in Belarus. At the same time articles about Georgian experience of E-Government system creation was used for better understanding the influence of Government digitalization on shadow economy level.

\section{Main issues of construction sector development in Belarus}

Construction is an important component of the Belarusian economy. Since the beginning of independence, one of the main priorities of economic development has been the successful work of the construction sector. Turning to the statistics for the last seven years, it can be noted that the share of construction in GDP in 2010 was $9.4 \%$, and 
in 2014 the performance of this sector exceeded 10\% of GDP. In recent years, the significance of the construction sector has somewhat decreased (Fig. 1).

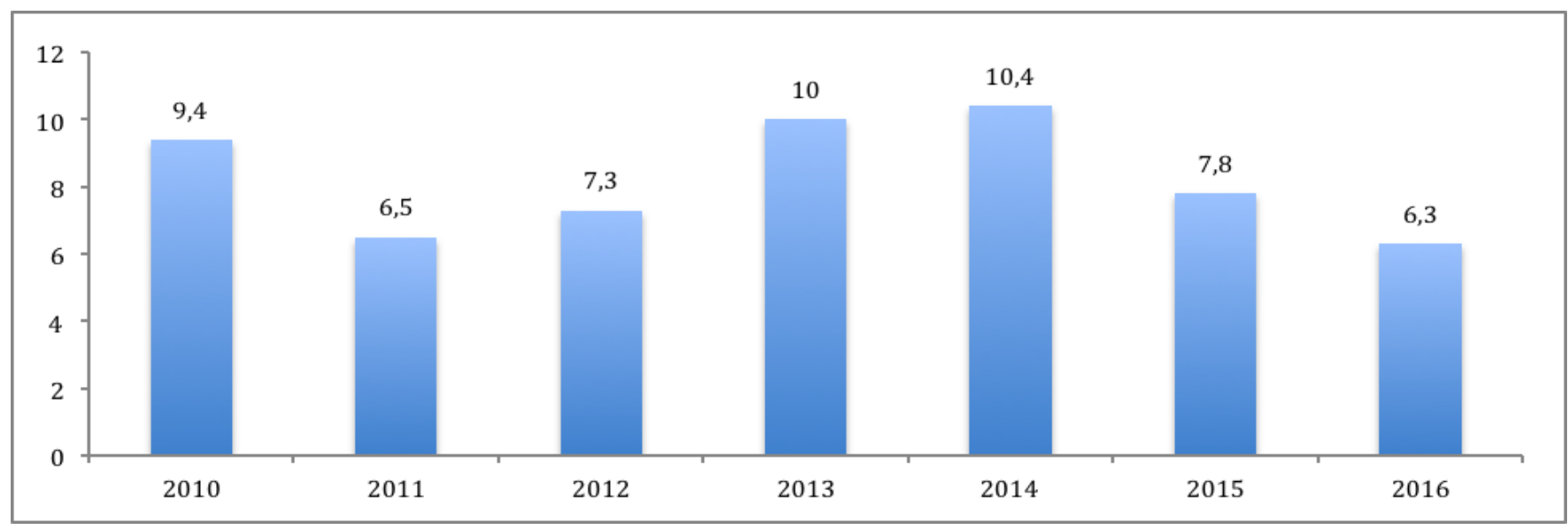

Figure 1. The share of construction sector in GDP (in \%)

Source: Belarusian National Statistical Committee

Such trends can be explained by reduction of the share of preferential loans in housing construction, as well as a slowdown in business activity, negative influence of external factors and reduction in domestic demand. As follows from the graph below, in 2016 compared with 2010, the main difference between the structure of sources of housing finance was a sharp reduction in preferential loans in housing construction. At the same time, there was growth of the share of housing construction financing provided by the population from their own savings. Given that the income of the population has also declined due to the economic recession, the volume of housing construction has had a negative growth rate (Fig. 2).

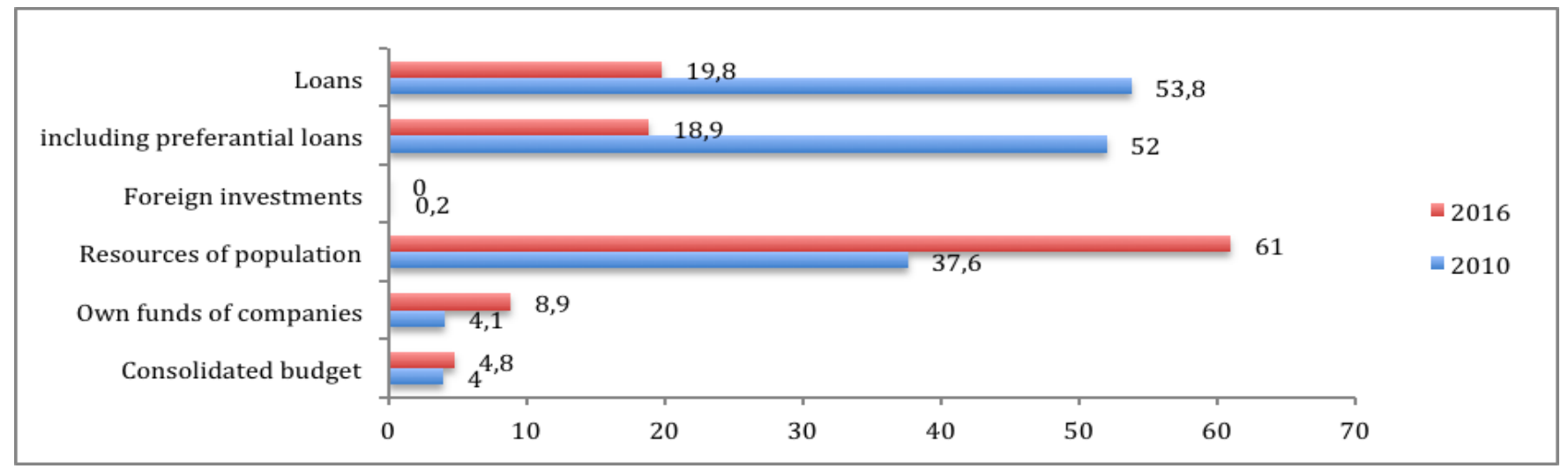

Figure 2. Structure of housing construction by source of financing (in \%)

Source: Belarusian National Statistical Committee

The economic slowdown observed in recent years also supported to a reduction in aggregate investment activity, which had a negative impact on the housing construction and commercial real estate. Nevertheless, construction is still an important sector of the national economy. About $8 \%$ of total labour force of the country is concentrated in this sector.

The main part of construction organizations has a private form of ownership. Despite the fact that about 7.5 
thousand construction companies are registered, more than $90 \%$ of them are represented by small and mediumsized businesses. The vast majority of construction companies are presented by firms with less than 100 employees (Fig. 3). It is also worth noting that foreign companies in the construction sector occupy slightly more than $1 \%$ of the total number of organizations. Thus, for today there is no serious interest of foreign capital to invest into construction sector of the Republic of Belarus (Fig. 4).

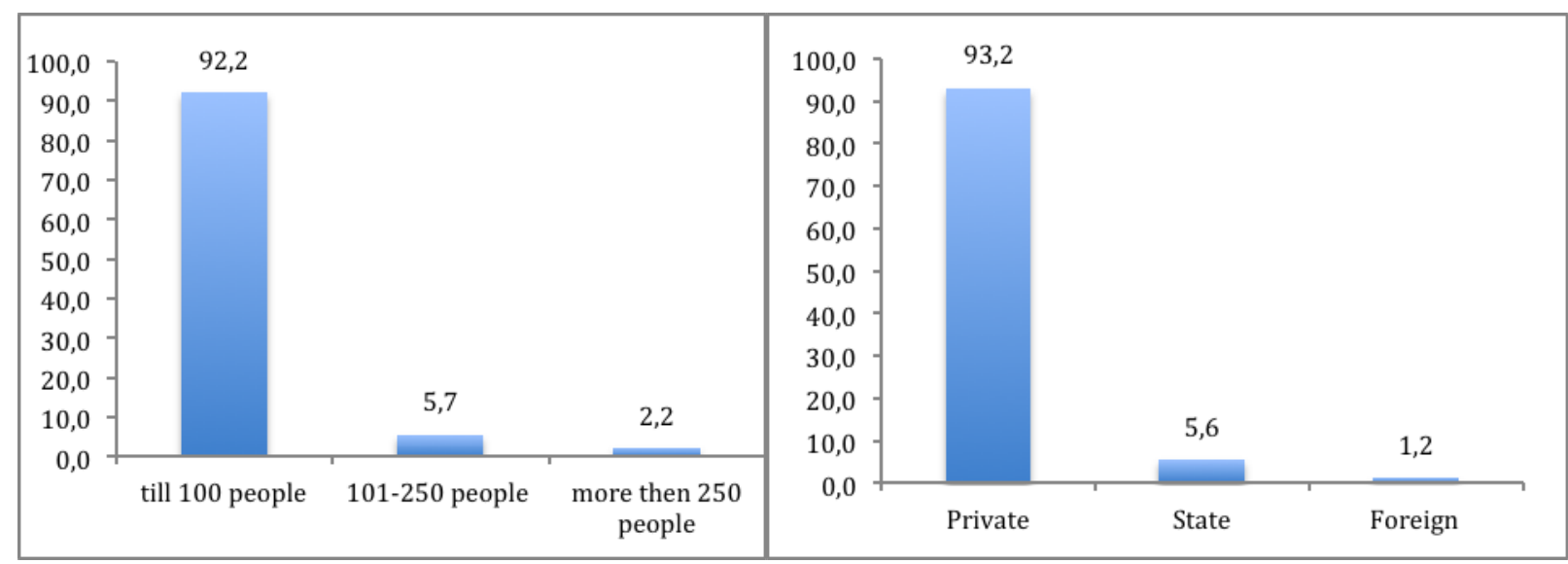

Figure 3. Structure of construction sector organizations by number of employees at the beginning of $2016^{\dagger}$ (in \%)
Figure 4. Structure of construction sector organizations by ownership form at the beginning of 2016 (in \%)

Source: Belarusian National Statistical Committee

Source: Belarusian National Statistical Committee

Therefore, despite the decline of the construction share in recent years, this sector is still one of the main resource of GDP formation. A high share of private capital says about the attractiveness of construction for business. At the same time, foreign investors in the construction market are represented insignificantly. It should be noted that the development of the construction sector depends on the economic and legal environment, as well as on transparency and openness of transactions. One of the problems limiting the growth of the efficiency of the construction industry in the country is the existence of shadow economy elements in this segment.

\section{The level of shadow economy and its calculation}

Existence of shadow economy, which includes corruption practices and tax evasion, is typical for many countries. However, in some states the level of shadow economy is relatively low, while in others it has a relatively high share in GDP. Clearly determine the real level of shadow economy is very difficult. It is too problematic to specify the situation with corruption and tax evasion in the construction sector. One of the most popular indexes, allowing to assess the level of corruption in a country is the Corruption Perceptions Index. This Index is calculated annually for more than 170 countries. The Republic of Belarus also participates in this survey (Table 1). According to the latest survey, it was revealed that the level of corruption directly affects the level of equality and equitable distribution of wealth.

\footnotetext{
$\dagger$ Organizations of construction sector include companies with the main economic activity - "Construction". These include legal entities of all forms of ownership, separate units of legal entities, small and microorganizations without departmental subordination, performing work under agreements of construction (subcontracts) classified by economic activities as "Construction."
} 
Table 1. Corruption Perceptions Index 2016

\begin{tabular}{|c|c|c|c|c|}
\hline 2016 Rank & Country & 2016 Score & 2015 Score & 2014 Score \\
\hline 1 & New Zealand & 90 & 88 & 91 \\
\hline 3 & Finland & 89 & 90 & 89 \\
\hline 4 & Sweden & 88 & 89 & 87 \\
\hline 5 & Switzerland & 86 & 86 & 86 \\
\hline 44 & Latvia & 57 & 55 & 55 \\
\hline 54 & Slovakia & 51 & 51 & 50 \\
\hline 79 & Belarus & 40 & 32 & 31 \\
\hline 131 & Russia & 29 & 29 & 27 \\
\hline 131 & Kazakhstan & 29 & 28 & 29 \\
\hline
\end{tabular}

Source: Official website of Transparency International. Available on the Internet: https://www.transparency.org/

The index' calculation is based on a comparison of the countries participating in the survey, according to the points scored by them. The more points received the country, the higher will be its rating. Traditionally the top ten leaders are Scandinavian countries, Switzerland, Great Britain, Denmark, Canada, Singapore, New Zealand and the Netherlands.

As for the countries of the former Soviet space, the situation with the level of corruption has significant differences depending on the state. For example, Belarus occupies the 79th position in this rating. This level means a much higher level of corruption compared to Latvia, which ranks 44th place in this list. At the same time, the situation in Belarus is much more favourable compared with Russia and Kazakhstan, which shared 131 lines in the rating. As for the aggregate level of the shadow economy in the country, the data on this issue vary greatly. The Ministry of Taxes, as well as the Belarusian National Statistical Committee, inform that the level of shadow economy is not exceeding 11-12\% of GDP. At the same time, the experts from the National Bank has announced that this indicator can reach the level of 35\% of GDP. Of great importance in this matter is the methodology of calculation and its systematic. The lack of constant monitoring of the situation and special methodology absence creates a certain ambiguity and inconsistency of the data.

In our view, for understanding the most problematic points in the sphere of the shadow economy it would be useful to start calculating the index of the shadow economy in Belarus, following the experience of the Baltic States. This index is calculated on the basis of data from the annual survey of companies in Latvia, Lithuania and Estonia. This survey allows us to determine not only the aggregate level of the shadow economy, but also to calculate the amount of unaccounted incomes and the level of illegal activity by the main sectors of the economy, as well as by the regions of a country, the size of enterprises and other parameters. Conducting this research would undoubtedly increase the quality and effectiveness of measures which to support the reduction of the shadow economy level in the country.

Despite the lack of detailed data, experts and officials say that the construction sector is one of the most problematic sectors of the Belarusian economy in terms of opacity of transactions and abuses. Problems arise as 
on the stage of state procurement procedure so on different stages of economic activities of the construction organizations. In order to understand the real situation in the sphere of the shadow economy and analyse the prerequisites for its development, a survey of construction sector enterprises was conducted. The survey was based on a method developed by Latvian experts (Arnis Sauka and Talis Putnis). The survey of enterprises consists of three parts. The first part includes indicators that allow us to evaluate the work of enterprises in construction sector from an economic point of view. Such indicators include the number of employees, the form of ownership of enterprises, the year of foundation, the amount of profit, the average wage and etc. The second group of questions makes it possible to understand the existence and the share of the informal sector in construction, by determining such indicators as the number of unregistered workers, the level of hidden income and the main problems that the respondents face. Finally, the third part of the survey concerns public procurement, including an assessment of the legislation' quality and problems in this area.

Despite the fact that the survey was conducted anonymously, many respondents reacted cautiously to some survey questions. Therefore, this report can be considered as one of the stages of work on assessing and monitoring the level of shadow economy in the country. It allows to identify the most problematic points that made it possible to develop recommendations on reduction corruption and tax evasion in the construction industry.

\section{Results of the Survey}

50 companies of construction industry took a part in the survey. The distribution of companies was as follow: 20 construction enterprises were interviewed in Minsk and Minsk region; 30 organizations of construction sector were interviewed in other 5 regions of Belarus ( 6 organizations were interviewed in Grodno region, 6 - in Brest region, 6 - in Vitebsk region, 6 - in Mogilev region and 6 - in Gomel region). The main part of the respondents has a private form of ownership. At the same time, $28 \%$ of the surveyed companies were state-owned.

The survey revealed that $32 \%$ of companies were created even before the collapse of the Soviet Union. However, the creation of the most part of the companies (44\%) was in the period from 1991 to 2011. At the same time 24\% of construction companies appeared in the last 5 years (Fig. 5).

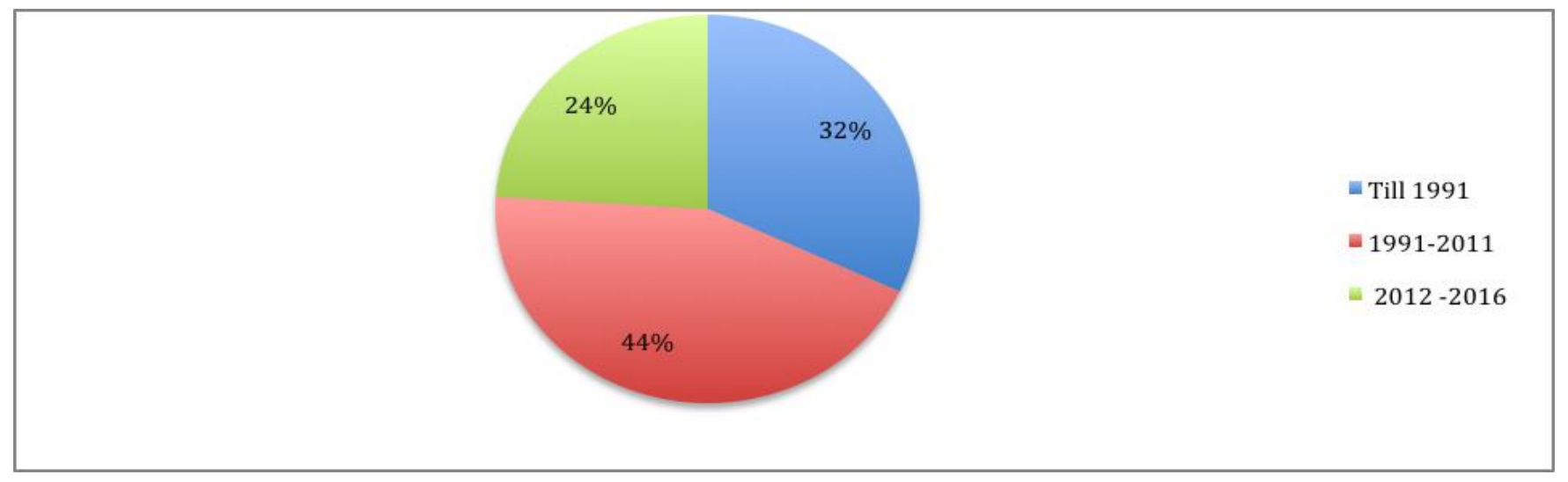

Figure 5. Companies' distribution by period of starting work in construction sector

Source: Results of the Survey

The sample of construction companies as a whole reflects the nationwide structure of construction companies, depending on the size. Small and medium-sized enterprises account for almost $43 \%$ of all respondents. Another $26.5 \%$ can be attributed to microenterprises and individual entrepreneurs. At the same time, only slightly more than $30 \%$ of the companies surveyed can be classified as large. The division of companies by size was based on the number of employees. The reason is that in accordance to the Belarusian legislation large companies include organizations with more than 250 employees. Microenterprises have a staff, which cannot be more than 15 
employees. At the same time, the number of employees in small and medium-sized businesses can vary from 16 to 250 people (Fig. 6).

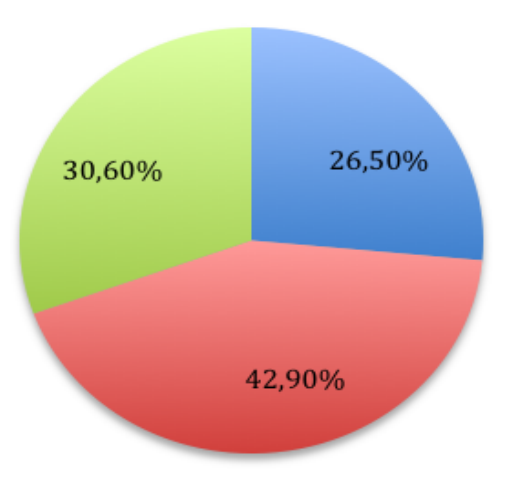
Individual entrepreneurs and micro companies
- Small and medium business

Large companies

Figure 6. Companies' distribution depend on size

Source: Results of the Survey

More than half of the surveyed companies had an average salary in the range of 300-500 euros in 2015-2016, while $36 \%$ respondents indicated a relatively low wage, which did not exceed 270 euros on average for the enterprise. And only $6 \%$ of respondents admitted that the average salary in this period was about 550-750 euros in equivalent. Thus, it can be noted that in most of the surveyed companies in the construction industry, the level of payment was comparable to the average wage in the country (Fig. 7).

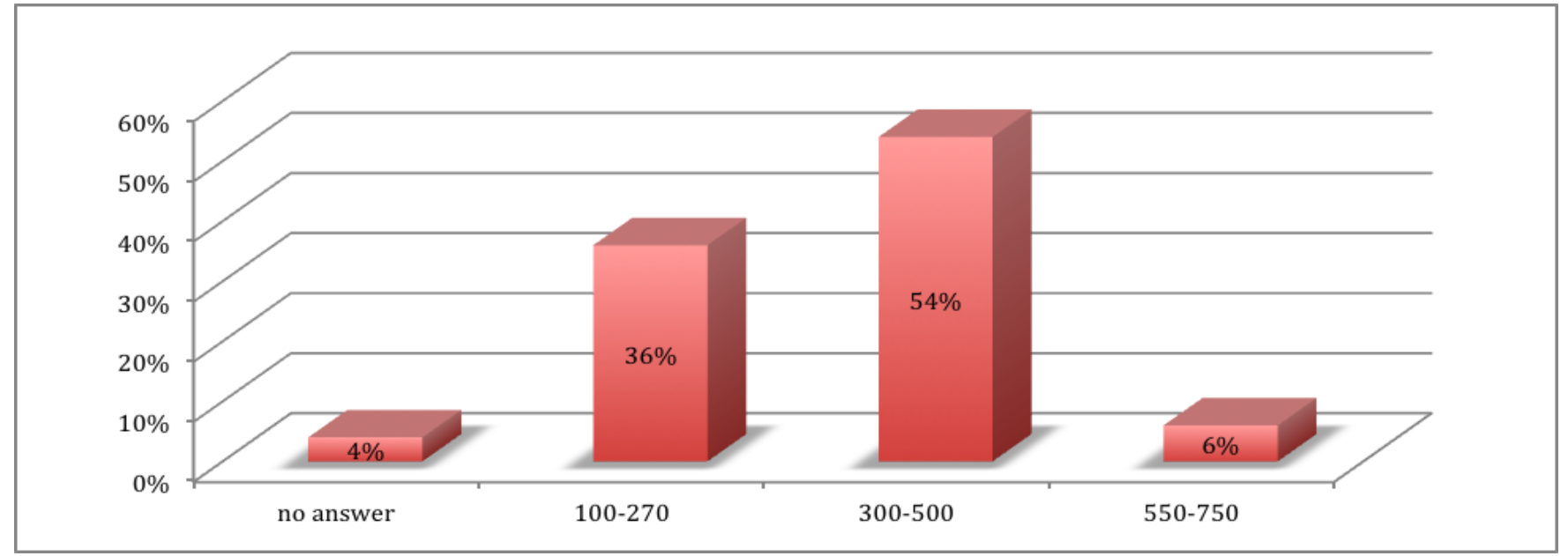

Figure 7. Distribution of the average level of wage in $2015-2016$ by respondents (X-axis - average wage in euro equivalent)

Source: Results of the Survey

It should also be noted that the survey of corporations was conducted in the conditions of economic recession, which affected on the importance of problems that are obstacles for the successful work of construction organizations. In these conditions, economic factors came to the fore. Managers and management of companies are concerned about finding out the markets, attracting new customers and reducing risks in conditions of high inflation and exchange rate volatility. As can be seen on the graph below, more than $40 \%$ of the respondents 
interviewed admitted that the net profit received in 2016 decreased compared to the level of 2015 . At the same time, only $28 \%$ of enterprises noted positive growth of this indicator (Fig. 8).

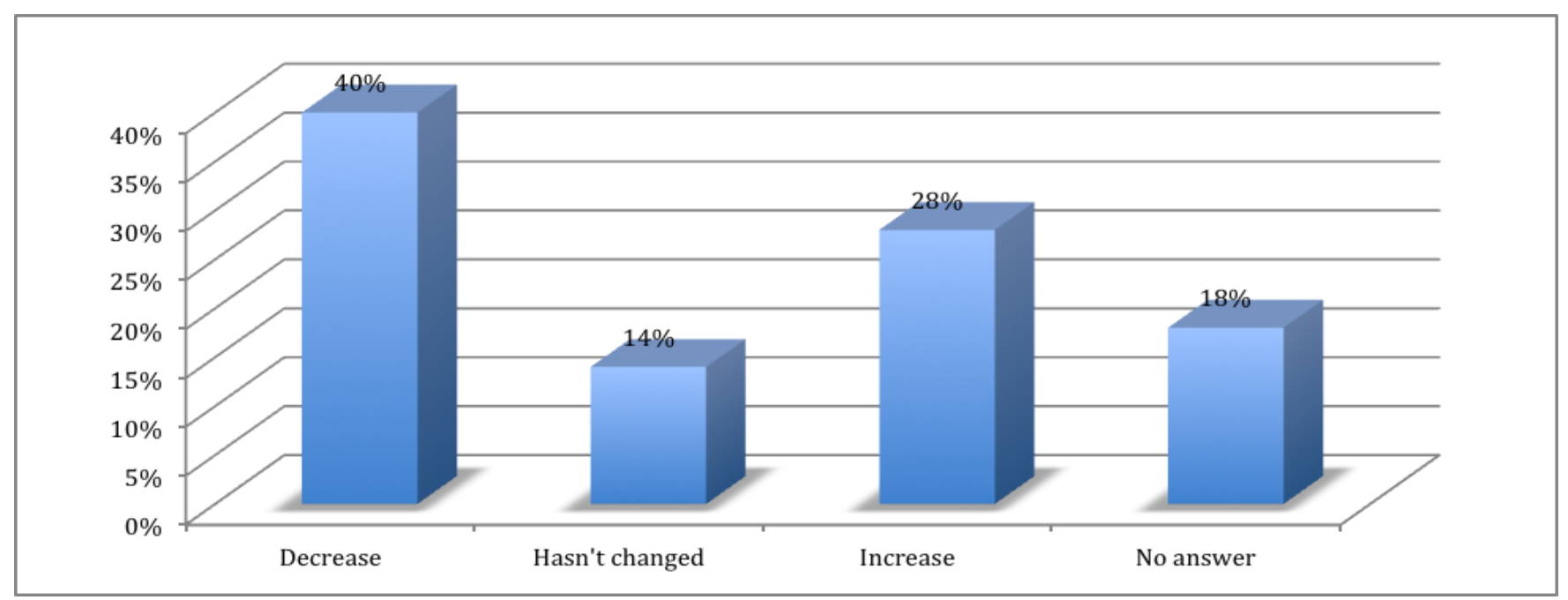

Figure 8. Changes of net profit in 2016 compare to 2015 ( $\mathrm{Y}$ axis - $\%$ of answers)

Source: Results of the Survey

The worsening of the financial situation also affected on the level of employment in the organizations of construction sector. Based on the survey results, $34 \%$ of construction companies experienced a reduction of the number of employees in 2016 compared to 2015. Only 22\% of respondents noted an increase of the number of employees. This dynamics is similar to the general trend in the whole country. According to the National Statistical Committee, in January-December 2016, compared to January-December 2015, the number of employees hired in construction amounted to $74.7 \%$ of the total number of employees who were dismissed at that period. It should be noted that in the whole economy this ratio was equal to $89.6 \%$ (Fig. 9).

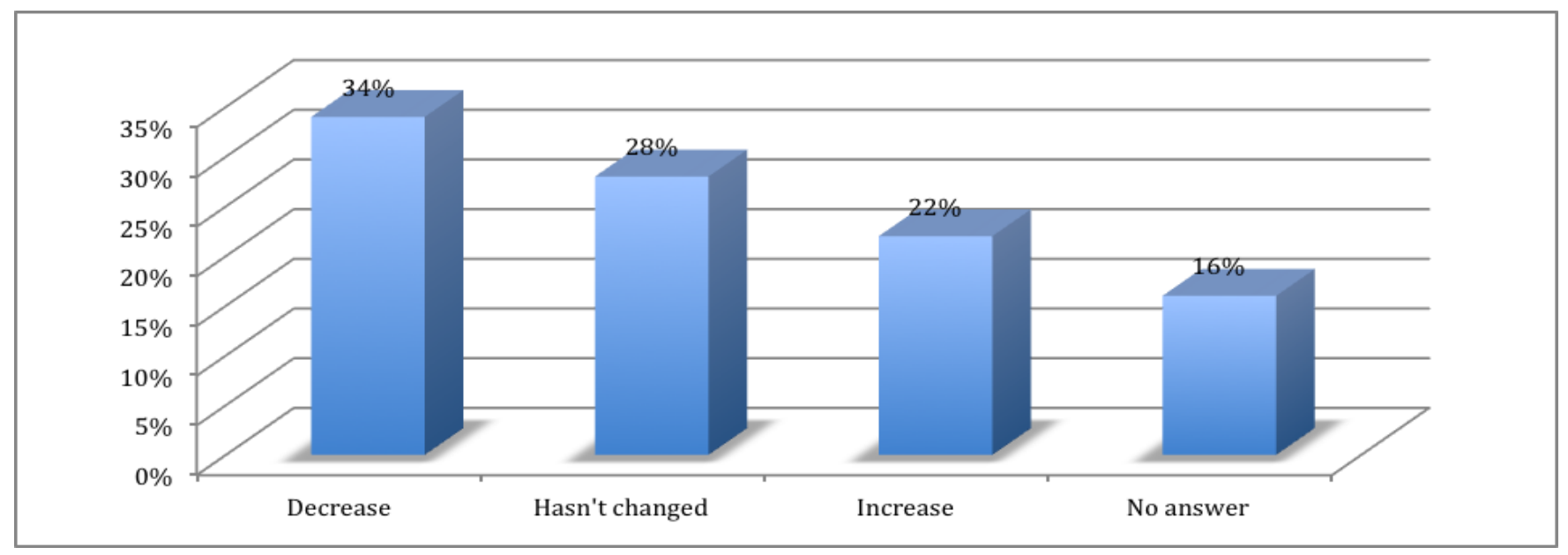

Figure 9. Changes of employment ( $\mathrm{Y}$ axis $-\%$ of answers)

Source: Results of the Survey

More than $60 \%$ of respondents noted that some construction organizations receive some part of income in hidden form. At the same time, 18\% simply refused to answer the question (Fig. 10). Among the respondents, about 50\% 
of total companies believe that construction companies do not always show the actual number of employees. A certain number of hired people can be employed unofficially ( Fig. 11).
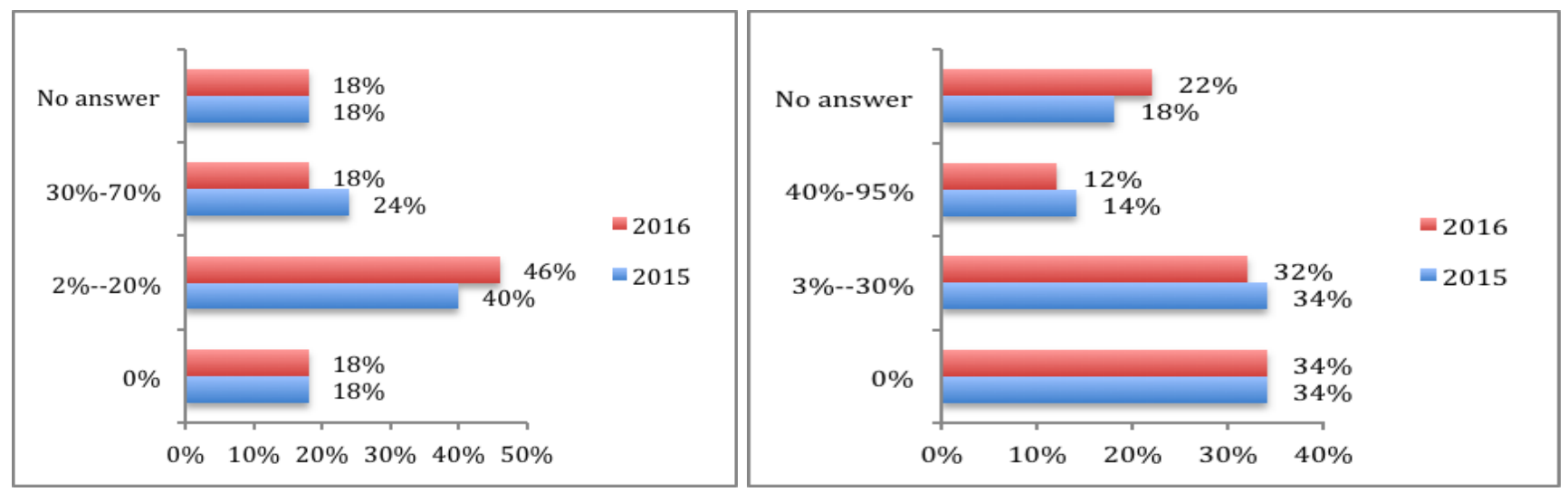

Figure 10. Approximate level of underreporting of income (hidden income) in construction industry ( $\mathrm{X}$ axis - \% of respondents which are agree with this statement)
Figure 11. Approximate level of underreporting employees in the construction sector (X axis - \% of respondents which are agree with this statement)

Source: Results of the Survey

Source: Results of the Survey

As it turned out during the survey for the construction industry, there is a problem of paying wages "in envelopes". Approximately 50\% of the interviewed companies agreed with this statement. From the total number of respondents, $26 \%$ believe that the share of hidden wages in both 2015 and 2016 ranged from 21 to 50\%. Some respondents said that unofficial payments to their employees could reach more than $50 \%$ of the total volume of payments (this was noted in 12\% of companies in 2015 and 14\% in 2016). At the same time, some firms refused to answer on the question. It is also alarming that about $60 \%$ of the respondents believe that part of the industry's production is carried out by unregistered companies. This means, on the one hand, a shortage of the generation of taxation revenue, and on the other - the absence of any control over the activities of such pseudo-firms. As an example of such illegal production, we can cite the repair services provision for apartments and private houses by unregistered construction firms (teams) (Fig. 12; Fig. 13).

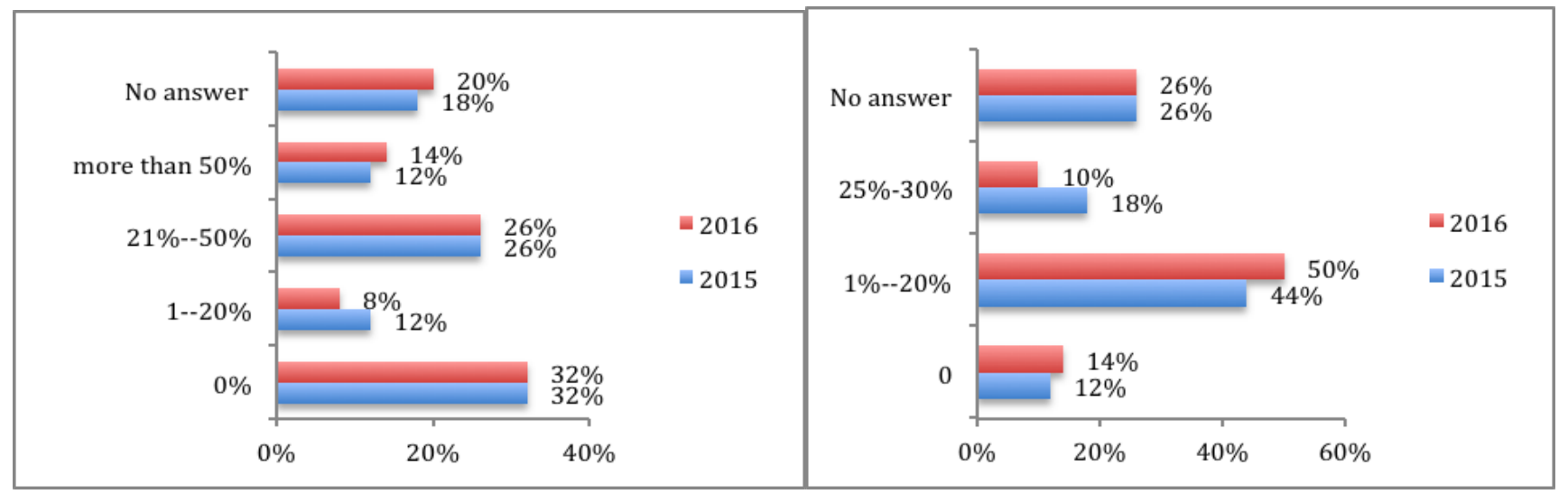

Figure 12. Estimation of the approximate level of hidden salaries ("wages in the envelopes") in construction industry ( $\mathrm{X}$ axis - \% of respondents which are agree with this statement)

Source: Results of the Survey
Figure 13. Estimation of approximate share of production of unregistered firms in the total volume of production in construction industry ( $\mathrm{X}$ axis - \% of respondents which are agree with this statement)

Source: Results of the Survey 
Proceeding from the foregoing, it can be assumed that the Belarusian budget has lost some of the revenues in the form of taxes on corporate income, social contributions and wage taxes due to underreporting by the construction industry companies of total income, payments wages 'in the envelopes', and informal hiring of some share employees.

As for issues directly related to corruption schemes, some respondents refused to answer on some questions. When we asked about the share of income that firms pay unofficially to 'get things done', more than $30 \%$ of respondents noted that this percentage can vary within $10 \%$. Some companies said they answered that this figure can reach even more then $30 \%$ of total income. A roughly similar division of answers was received on the question of the share of contract value that is usually offered by companies in the form of unofficial payments in order to sign a contract with the state. More than a quarter of the companies refused to answer on these questions (Fig. 14, Fig. 15).

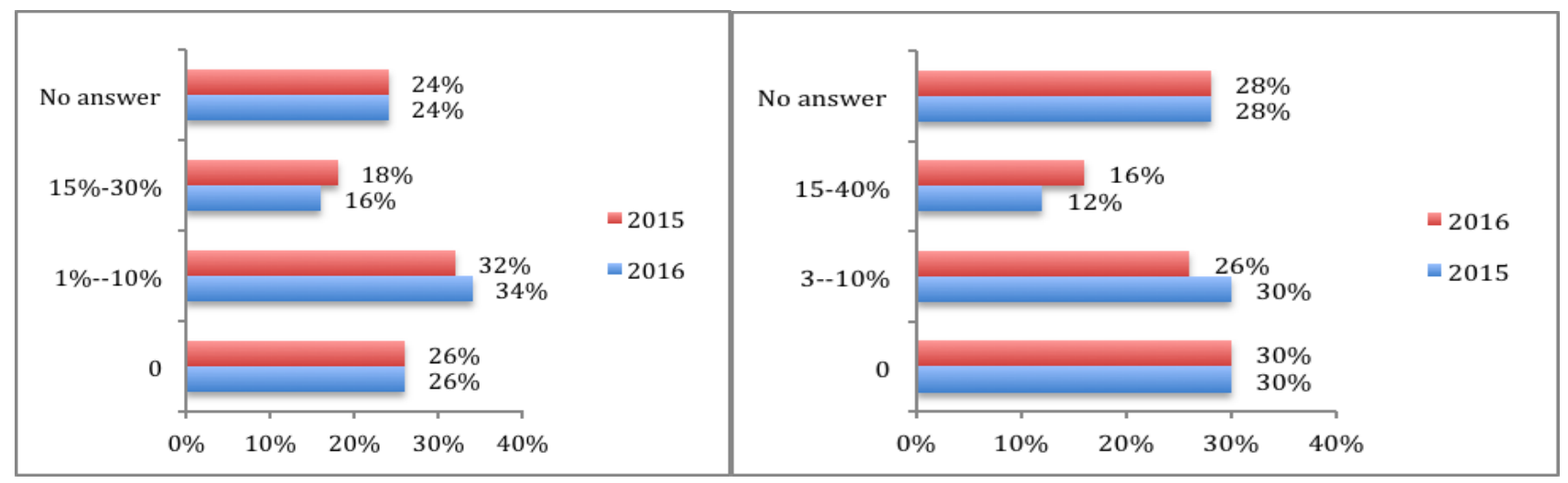

Figure 14. Estimation of the approximate level of income that firms pay unofficially to 'get things done' ( $\mathrm{X}$ axis - \% of respondents which are agree with this statement)

Source: Results of the Survey
Figure 15. Estimation of aapproximate percent of the contract value would firms typically offer in unofficial payments to 'secure' the contract ( $\mathrm{X}$ axis - \% of respondents which are agree with this statement)

Source: Results of the Survey

Enterprises were also asked to agree or not with statements which can be obstacles for business development. The results of the answers are given in the Table 2.

Table 2. Main barriers to the business development in construction sector in Belarus

\begin{tabular}{|c|c|c|c|c|c|}
\hline & 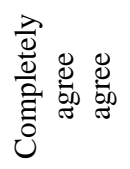 & 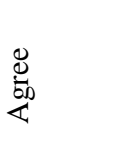 & 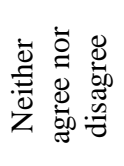 & 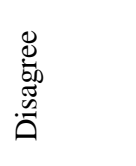 & 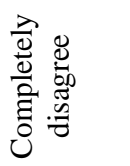 \\
\hline Taxes are too high & $36,0 \%$ & $50,0 \%$ & $14,0 \%$ & $0,0 \%$ & $0,0 \%$ \\
\hline Frequent changes in tax policies & $14,0 \%$ & $46,0 \%$ & $36,0 \%$ & $4,0 \%$ & $0,0 \%$ \\
\hline Inconsequent business legislation & $26,0 \%$ & $40,0 \%$ & $28,0 \%$ & $6,0 \%$ & $0,0 \%$ \\
\hline
\end{tabular}


The International Journal

ENTREPRENEURSHIP AND SUSTAINABILITY ISSUES

ISSN 2345-0282 (online) http://jssidoi.org/jesi/

2017 Volume 5 Number 2 (December)

http://doi.org/10.9770/jesi.2017.5.2(8)

\begin{tabular}{|c|c|c|c|c|c|}
\hline $\begin{array}{l}\text { Implementation of business legislations by the } \\
\text { government as a consequence of bad administration and } \\
\text { lack of personnel }\end{array}$ & $16,0 \%$ & $32,0 \%$ & $32,0 \%$ & $20,0 \%$ & $0,0 \%$ \\
\hline $\begin{array}{l}\text { Information provision by the government to small and } \\
\text { medium firms }\end{array}$ & $14,0 \%$ & $32,0 \%$ & $36,0 \%$ & $18,0 \%$ & $0,0 \%$ \\
\hline $\begin{array}{l}\text { Lack of specific consulting advice on marketing, } \\
\text { financial, psychological issues }\end{array}$ & $12,0 \%$ & $20,0 \%$ & $40,0 \%$ & $26,0 \%$ & $2,0 \%$ \\
\hline Lack funds for business investments & $26,0 \%$ & $42,0 \%$ & $22,0 \%$ & $8,0 \%$ & $2,0 \%$ \\
\hline Access to credits & $20,0 \%$ & $38,0 \%$ & $32,0 \%$ & $8,0 \%$ & $2,0 \%$ \\
\hline Too many tax inspections & $12,0 \%$ & $30,0 \%$ & $50,0 \%$ & $8,0 \%$ & $0,0 \%$ \\
\hline Crime and racketeering & $2,0 \%$ & $8,0 \%$ & $24,0 \%$ & $52,0 \%$ & $14,0 \%$ \\
\hline Payment behaviour of clients & $18,4 \%$ & $49,0 \%$ & $24,5 \%$ & $6,1 \%$ & $2,0 \%$ \\
\hline Attitude the government towards business in general & $20,0 \%$ & $28,0 \%$ & $32,0 \%$ & $16,0 \%$ & $4,0 \%$ \\
\hline Time spent negotiating with tax inspectors & $10,0 \%$ & $26,0 \%$ & $40,0 \%$ & $20,0 \%$ & $4,0 \%$ \\
\hline Governmental corruption & $18,0 \%$ & $34,0 \%$ & $18,0 \%$ & $28,0 \%$ & $2,0 \%$ \\
\hline Motivation of employees & $12,0 \%$ & $26,0 \%$ & $22,0 \%$ & $32,0 \%$ & $8,0 \%$ \\
\hline High competition from legal business & $10,0 \%$ & $26,0 \%$ & $44,0 \%$ & $20,0 \%$ & $0,0 \%$ \\
\hline High competition from illegal business & $8,2 \%$ & $30,6 \%$ & $32,7 \%$ & $22,4 \%$ & $6,1 \%$ \\
\hline Low purchasing power & $44,0 \%$ & $38,0 \%$ & $14,0 \%$ & $2,0 \%$ & $2,0 \%$ \\
\hline Shortage of qualified workers & $12,0 \%$ & $28,0 \%$ & $22,0 \%$ & $32,0 \%$ & $6,0 \%$ \\
\hline Shortage of qualified managers & $20,0 \%$ & $14,0 \%$ & $38,0 \%$ & $26,0 \%$ & $2,0 \%$ \\
\hline Inflation & $22,0 \%$ & $54,0 \%$ & $24,0 \%$ & $0,0 \%$ & $0,0 \%$ \\
\hline Low product/ service demand from customers & $26,0 \%$ & $34,0 \%$ & $22,0 \%$ & $16,0 \%$ & $2,0 \%$ \\
\hline Inability to grow into new markets & $24,0 \%$ & $28,0 \%$ & $34,0 \%$ & $12,0 \%$ & $2,0 \%$ \\
\hline
\end{tabular}

Source: Results of the Survey

The above-mentioned factors can be divided into three groups. These are administrative obstacles, economic difficulties and problems associated with the functioning of the shadow economy. Based on the results of the Survey, it can be concluded that all three groups of factors have a negative impact on business development, for more or less extent. First of all, companies are concerned with taxation issues, unsatisfactory state-to-business relations, and inconsistency of legislation in the sphere of business regulation. Among the economic factors, we can highlight a high level of inflation, credit problems, the inability to grow on new markets, as well as low demand from customers and buyers. As for questions about corruption, the majority of respondents confirmed the impact of this negative factor. More than $50 \%$ of respondents believe that the presence of corruption has a negative impact on business development and $18 \%$ noted that they rather agree than disagree with this statement. 
At the same time, $30 \%$ of respondents did not agree with this fact. An approximately similar structure of responses is observed about the assertion about the negative impact of competition from the informal business. A positive fact is that most organizations have excluded crime and racketeering barriers on business development. Thus, the problems of corruption and the existence of a shadow economy worry most of the companies surveyed, and the discontent with the level of corruption is more pronounced. It should be noted that inefficient state regulation, as well as economic problems, indirectly create the basis for the development of "grey" schemes both in the economy as a whole and in the construction sector in particular. In the third part of the survey, respondents were asked to answer the questions related to the implementation of public procurement. It should be noted that this list of issues was perceived negatively, as a result of which some respondents refused to answer most of the questions posed about public procurement. From the fifty companies, twenty nine said that they had participated in public procurement over the past two years. At the same time, twenty four companies noted that during this period they were able to win the tender (Fig.16).

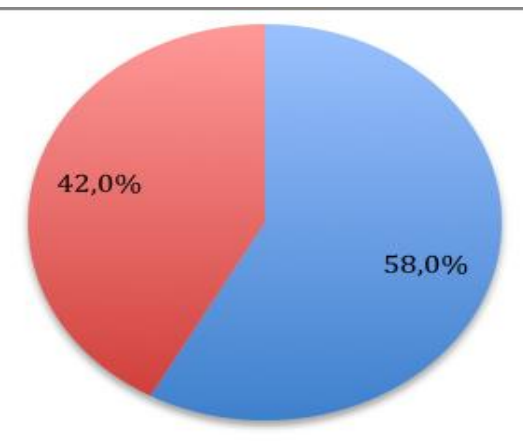

Figure 16. Answer on the question: Have your company participated in municipal procurements over the past two years?

Source: Results of the Survey

When asked about the number of organizations participating in a single tender for public procurement, the opinions of the respondents were also different. $20 \%$ of companies said that in tenders where they took part, up to 5 companies were participated usually, but $42 \%$ of construction companies noted that the number of competitors could vary from 6 to 20 companies. Thus, in this sphere there is a fairly high level of competition between the participants in the construction market. However, the presence of competition does not always prevent corruption dealings and schemes. For example, on the question about competitions in the sphere of public procurement, which your company lost due to unfair competition, $40 \%$ of respondents said that such cases have happened with them. Proceeding from the fact that more than $40 \%$ of the companies surveyed have not participated in tenders at all in the last two years, it can be assumed that most of the enterprises that had such experience believe that they faced unfair competition (Fig. 17). 


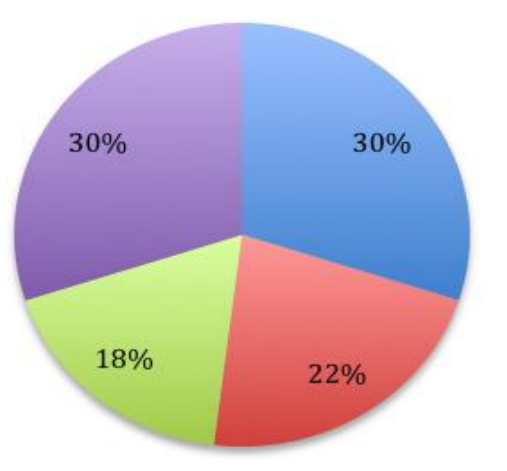

Figure 17. Answer on the question: On average, approximately what percent of municipal procurement competitions did you lose because they have been exposed to unfair competition? (Legend - range of lost tenders in \%)

\section{Source: Results of the Survey}

Based on the received answers, we could conclude that one of the reasons that create problems in public procurement is the imperfection of legislation. Only $8 \%$ of organizations noted that they are satisfied with the legislation on public procurement. At the same time, $42 \%$ of the respondents found this question is difficult for answering, that can be explained by the lack of experience of companies' participation in such competitions. At the same time, $46 \%$ of the respondents, that is the majority of those who have participated in public procurement in the last two years, have expressed their dissatisfaction with the current legislation in the field of regulation of public procurement (Fig. 18).

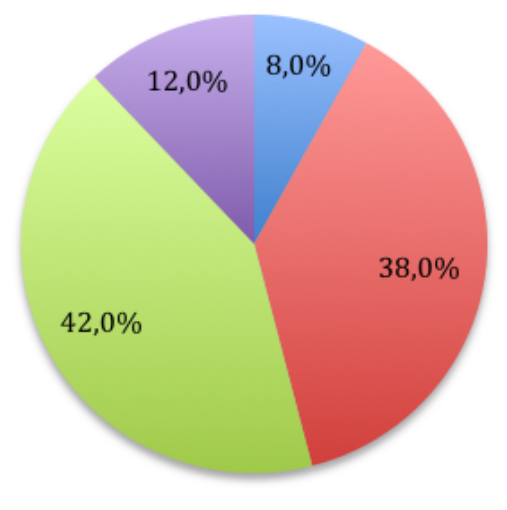

- Completely dissatisfied

Dissatisfied

Difficult to answer

- Satisfied

Figure 18. The level of satisfaction of legislation quality in the sphere of public procurement.

Source: Results of the Survey

A special role in the research is given to main problems that companies face when participate in public procurement tenders. As part of the survey, companies were asked to underline three main problems in this area. Respondents named a fairly wide range of problems. The main part of the received answers is presented below and divided into three categories: administrative reasons, economic factors and problems, problems associated with the existence of the shadow economy and corruption. 
ENTREPRENEURSHIP AND SUSTAINABILITY ISSUES

ISSN 2345-0282 (online) http://jssidoi.org/jesi/

2017 Volume 5 Number 2 (December)

http://doi.org/10.9770/jesi.2017.5.2(8)

Problems of public procurements system from the companies' point of view:

Economic

Inflation;

High competition;

Low level of profit;

Incompetence, high demands and bad fulfilment of obligations by customers;

Low consumer abilities of the population;

Non-performance of obligations on the financing;

Financing.

Administrative:

Low level of information technology implementation in the public procurement procedure;

Complexity of necessary documentation preparation;

Unequal conditions for public and private enterprises;

A large number of fines and public inspections;

Bureaucracy;

Imperfection of legislation.

Problems associated with the existence of corruption and shadow economy

Personal agreement, nepotism, everything is decided in advance;

Corruption;

Unfair competition;

Non-transparency of competitions' procedures;

Non-commercial relations between companies;

The system of kickbacks;

Untimely notice of the beginning of the competition.

The chart below shows the main problems that are most popular among companies' responses (Fig. 19)

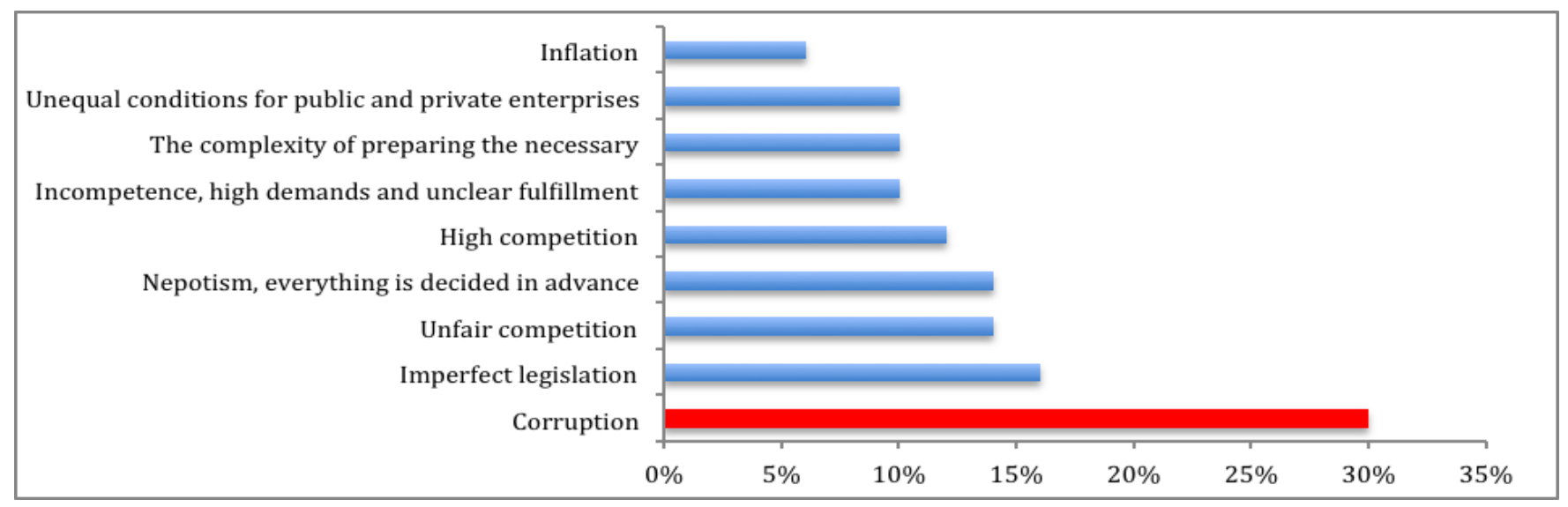

Figure 19. Main problems that companies face when participate in public procurement tenders (X axis - \% of respondents, which are agree with this statement)

Source: Results of the Survey

As we can see on the chart above, the most important problem in public procurement is the problem of corruption. This factor was highlighted by $30 \%$ of the respondents. In addition, a number of companies noted that important problems for them are also related with unfair competition and nepotism, everything is decided in advance. Among the administrative barriers, the most important factors include the imperfection of the legislation, and the complexity of the documentation. Finally, among the economic barriers most popular answer include the problems of working with customers and unequal conditions for public and private enterprises. 


\section{Ways of declining the level of corruption and tax evasion in construction sector of Belarus}

Thus, based on the analysis, we can conclude that Belarusian construction companies face a number of problems and risks in their activities. Undoubtedly, one of the important conditions that are indirectly stimulates the growth of corruption transactions and shadow economy development is the inconsistency and variability of legislation. Due to the fact that the rules for public procurements are constantly changing, it is very difficult for enterprises to follow them constantly.

As an example, we can cite legislation in the field of procurement, construction works and services. Till the beginning of 2017, the implementation of purchases, wholly or partly, carried out by the resources of budgetary funds, state extra-budgetary funds and procurements from non-state sources were regulated by various legislative acts. From the beginning of the year, all purchases in the construction sector should be conducted in accordance with Presidential Decree No. 380 "On Procurement of Goods (Work, Services) during Construction" $"$. This document is valid for the period until the end of 2018. Then, perhaps, some conceptual changes will be made again.

In accordance with new legislation, the procurement of goods can be carried out by means of tenders, negotiations or exchange tenders, and for the procurement of works and services, it is necessary to apply contractual tenders or negotiations. In the legislation of public procurement in generals, the ways of implementing them are more diverse. At the same time, contract tendering in construction must be mandatory only when housing construction is carried out, if the total cost is more than 6 thousand base units and construction is fully or partially financed by resources from budgetary funds, if the total cost is more than 6 thousand base units, as well as for construction of facilities from the resources of state organizations and legal entities with the share of state ownership, if the cost of construction according to the contract is more than 100 thousand base units. The tender is optional if it was declared invalid because the winner is not determined or refused the contract. It is also possible to exclude the tender procedure if the contract was signed between general contractor and subcontractors. On the one hand, these changes in legislation simplify the procurement process as well as selection of contractors and subcontractors. On the other hand, they do not significantly increase the transparency of transactions. In addition, the adopted norms will be valid only for 2 years. After that, cardinal changes can occur again. However, instability, and the complexity of legislation are often main factors that stimulate the shadow market development. In this regard, it would be optimal to develop the basic legislative norms, which regulate the construction sector and then carry out only their improvement.

Based on national and international experience, it is necessary to raise the problem of the relationship between the contractor and subcontractors. In Belarus, as in many other countries, these operations remain relatively opaque even for those projects that are financed from the budgetary funds. In the case of a multilevel structure of interaction between subcontractors, it is very difficult to trace the effectiveness of the resources use. In addition, there is the issue of transparency of the procurement process, if the tender was declared invalid. In this case, it is possible to apply the negotiation procedure, which reduces the level of openness of the transaction also. Based on the conducted survey of enterprises there is a problem of subjectivity of the procurement process. This means that the procedure cannot be carried out without direct interaction between the tender organizers and the contractors. Minimizing the human factor reduces the risk of abuse. This is especially true in the sphere of public

\footnotetext{
\$ Public procurement in the construction sector was regulated by the Law «About Public Procurement of Goods (Work, Services)». Private procurements regulated by Decree of the President of the Republic of Belarus No. 591 of 31.12.2013 «About Conducting Procurement Procedures in Construction» and by Government resolution No. 88 of 31.01 .2014 «About organization and implementation of procedures for the procurement of goods (works, services) and settlements between customer and contractor in the facilities construction».
} 
procurement. Therefore, according to our opinion, the digitalization and general openness of the process is very important in the conduct of public procurement auctions in the construction sector. These changes will reduce the level of corruption without tightening penalties.

A positive example in this area is Georgia's experience. In this country, trades are conducted in electronic form on the basis of Agency of Public Procurement. Organizers of the auction don't know which of the suppliers participate in the tender. It is possible because each participant is assigned his own impersonal number. In addition, information about the auction is known in advance and is constantly available in Internet. At any time of the day interested persons can get information about required documentation and, thus, timely prepare for the tender. Each participant can challenge the decisions in Electronic Court for Dispute Resolution. After the tender, information about the winner becomes fully open. Also on the site of public procurement everybody can see what kind of payments were made and get detailed information about previous tenders.

The experience of Georgia is an example of the policy implementation in the sphere of open data. The essence of this system means the access by an ordinary user to any source of information in a machine-readable format with the exception of classified materials. In Russia, for example, this process is regulated by the Law on Open Data. A permanent dialogue between the state and society on the need to open this or that information is being conducted. One of the problems that experts face when developing this direction is the admission of errors in huge amounts of information. For example, when publishing public procurement data, a number of technical errors can be made. However, based on Russian experience, it can be concluded that these inaccuracies can be corrected by developing appropriate software. Thus, if detailed information is published on the ongoing transactions, procedures and processes, then this is mean that additional cooperation between society and the state is created. In such situation it is more difficult to hide the facts of abuse, including operations in the construction sector.

The next problem in the framework of construction is the verification of compliance of construction projects to the norms of the Belarusian legislation. In this case commissioning or non-commissioning of an object depends on the decision of individual experts from state institutions. And this is also a sphere for corruption. In this case it will be nice to propose the creation of independent organizations that would be interested in the fact that the objects, inspected by them meet, all necessary regulatory requirements and be put into service timely. These companies would be able to work as consultants and give an independent assessment of compliance. Such organizations can be compared with independent audit firms that help their clients to put in order bookkeeping without imposing any sanctions on them.

An important stage in reducing the level of the shadow economy is the digitalization of state organizations work, as well as transfer to the electronic format the interaction between state and business entities. In this case, we would like to suggest an e-government system creation. It should be noted that in Belarus there is still no clear plan of action for building an e-government system, as well as a regulatory or legislative act that regulate this area. There is only the program "Electronic Belarus". But if we turn to the experience of Estonia, for example, so in this country practically all state procedures can be carried out on-line. The avoidance of a personal contact in obtaining permits and licenses between state bodies on the one hand and legal entities and individuals on the other excludes the possibility of corrupt schemes. More over, next suggestion is related with organizing state procedures on the basis of blockchain principle. In this case, all participants of electronic network have the opportunity to see all transactions that are being performed. In addition, the committed transaction can not be cancelled or revoked, which allows everybody to track the chain of operations on each contract.

In continuation of the foregoing, we can also mention the need to create an effective electronic document system between state bodies, customers and contractors in construction. At present, the exchange of documents in electronic format is still duplicated by documents on paper. The economy and higher degree of openness of electronic documents will reduce the time and administrative costs, as well as will allow to increase the transparency of transactions. Thus, in order to reduce the level of corruption and "gray" schemes in construction, 
ENTREPRENEURSHIP AND SUSTAINABILITY ISSUES

ISSN 2345-0282 (online) http://jssidoi.org/jesi/

2017 Volume 5 Number 2 (December)

http://doi.org/10.9770/jesi.2017.5.2(8)

it is necessary to think about the speedy introduction of a full-scale digitalization of document circulation as well as formation of an e-government system. Possible risks in this direction can be related with costs of necessary changes. Belarus has much more population than Baltic states, Georgia or Finland. In this regard, the restructuring of the state institutions work will lead to significant material costs. Therefore, in order to adapt the world experience to national peculiarities and implement only effective projects, it should be possible to implement innovations on small territories (regions) on the basis of pilot projects. This suggestion also works for regulation and control of the construction sector, In this case, the implementation of certain actions in the field of the processes digitalization will not be accompanied by substantial capital investments. Successful projects should be further developed throughout the country, and less effective ones can be cancelled with minimal losses.

An important measure for declining the level of taxes evasion and reducing the risk of corruption schemes in the construction sector is the development of payments in a non-cash form. Despite the fact that according to the general rule enterprises and organizations must implement and accept payments in a non-cash form, a certain share of transactions remains in cash. This mainly concerns to operations between legal entities and individuals. Reduction the share of payments in cash form could be reached by decreasing of the maximum amount for conducting transactions in cash.

One of the most common examples of tax evasion is the execution of finishing works in private houses or apartments by unregistered construction teams or the lack of proper registration of contracts by legally functioning construction companies. Usually, such works performed by small businesses and individual entrepreneurs. «Grey» wages of construction workers are also quite a big problem for tax authorities. Currently, there is the possibility of hiring employees for a minimum payment. In this case part of incomes goes in the form of unaccounted (hidden) earnings. Partial solution of this problem could be the ID cards implementation for each employee. In this case, it would be clear how many people actually work and how their work is evaluated. The experience of Finland could be useful for Belarus. In this country, every employee of any construction company and employer must have his/her own ID card with the name of card's owner, taxpayer's number and the name of the employer. Tax authorities can check the information on the ID card on-line. The appropriateness of the information indicated on the card is verified by special labor inspectors. Sometimes checks are also conducted with the participation of police and tax authorities. In case of identified violations, personal responsibility is imposed.

In Finland cards implementation helped to identify all employees and employers working on the construction of a particular facility. At present, it is not difficult to obtain information about all workers and companies employed in the construction of a particular facility. In addition, the openness of the taxpayer's number allows the authorities to monitor the timely payment of income tax.

An important factor in the framework of tenders on public procurement in construction is the price. According to our opinion, the crucial importance of this particular criterion is not always justified. In Belarus some construction organizations can find the possibility to use correction factors for the price (for example, when hiring $50 \%$ of disabled staff) and unreasonably win the tender.In this case, it is advisable to take into account not only price like main parameter but also such indicators as manufacturability of the trading object and its financial return. In addition, it is possible to revise the list of entities that have incentives when participating in competitions.

Finally, as Georgia's experience shows, the level of corruption can be reduced by providing competitive salaries to employees of state institutions. High income level allows to attract well qualified specialists in the public sector. Economic interests can be created as by raising the level of wages, so by offering a social package. The formation of an effective system of control and punishment for unlawful acts is an important, but not the only element in fighting corruption in construction sector. The most important factor in this sphere is the openness and transparency of the work of state authorities, as well as the possibility of constant dialogue between state authorities and society. 


\section{Conclusions}

The survey of construction companies has showed the presence of problems associated with corruption and tax evasion in the construction sector. Based on the assessments of enterprises there are examples of concealment of the part of companies' income, as well as payments wages "in envelopes". Sometimes employers go on informal hiring of their employees, or spend part of their income unofficially to 'get things done'.

There are a lot of problems in the public procurements' system. The main negative factor in this area is corruption. In addition, construction companies identified such problems as nepotism, everything is decided in advance and unfair competition. Economic and administrative reasons have a negative impact on the public procurement system also. Many of these obstacles are related to the imperfection and variability of national legislation in the field of public procurement.

The world experience, as well as the analysis of construction companies' opinions, showed the need to develop a number of measures to reduce the level of corruption and tax evasion in the construction sector of Belarus. Among the main measures we can underline next:

- Improving the effectiveness of legislative acts (including the sphere of procurement in the construction sector) can be achieved by ensuring their stability and simplification of legislative norms execution.

- Increasing the transparency of procurement transactions in construction, as well as relations between contractors and subcontractors, can be enhanced by the unification of contract forms and transactions' transfer into electronic format.is[ip?

- Implementation of employees and employers identity cards is necessary for reduction the level of tax evasion.

- Ensuring the openness of data within the framework of the e-government system formation can be increased through the blockchain based procurement system implementation in construction.

- For reduction of excessive costs, it is possible to implement innovative solutions on the territory of one or several regions (pilot projects). In case of economic efficiency, successful projects should be further developed throughout the country.

- Information about past and future tenders should be available to all interested parties.

- The development of a non-cash payment system should also stimulate the transparency and openness of the transactions in construction sector.

— It is necessary to review the legislation for possible reduction the list of benefits and preferences for certain categories of organizations.

- Conducting trades should not always take into account the price as the main factor of tenders. In many cases, manufacturability of the trading object and its financial return have to be more or less equal importance.

- Increasing the status of civil servants, as well as providing them high wages, would reduce incentives for corruption, including in the construction sector.

- For constant monitoring of the shadow economy level, it is necessary to assess and research the level of corruption and tax avoidance, as at the country' level, so at the level of main economic sectors.

Thus, many steps have been done for reduction of shadow economy. According to the rating of Corruption Perception Index, the country places the better position than Russia or Kazakhstan. However the experience of such countries as Finland or Sweden shows opportunities for further reduction the level of informal sector and illegal operations. The focus should be done not only on punishment, but on creating attractive environment for business' development and reducing stimulus for corruption and tax evasion. 


\section{References}

About procurement of goods (works, services) in construction, Decree of the President of the Republic of Belarus of 20.10.2016, №380. Available on the Internet: $\underline{\mathrm{http}} / / / \mathrm{www}$. pravo.by/document/?guid=3871\&p0=P31600380

Anderson, E. (2013). Municipal "Best Practices": Preventing Fraud, Bribery and Corruption, International Centre for Criminal Law Reform and Criminal Justice Policy. Available on the http://icclr.law.ubc.ca/sites/icclr.law.ubc.ca/files/publications/pdfs/Municipal\%20Best\%20Practices\%20$\% 20$ Preventing $\% 20$ Fraud $\% 2$ C $\% 20$ Bribery $\% 20$ and $\% 20$ Corruption $\% 20$ FINAL.pdf

Briganti, F., Machalska, M., Steinmeyer, Heinz-Dietrich, Buelen, W. (2015). Social Identity cards in the European construction industry,

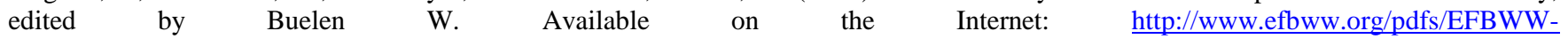
FIEC \%20report\%20on\%20social\%20ID\%20 cards\%20in\%20the\%20construction \%20industry.pdf

Capasso S., Jappelly T. (2011). Financial development and underground economy. Working paper \#298. Center of studies of economics and finance. University of Naples. Available on the Internet: http://www.csef.it/WP/wp298.pdf

Dreher, A., Kotsogiannis, C., McCorriston S. (2009), How Do Institutions Affect Corruption and the Shadow Economy?, International Tax and Public Finance, 16/4, pp.773-796

Fazekas, M., Toth, I.J., King, L.P. (2013). Corruption manual for beginners: “Corruption techniques" in public procurement with examples from Hungary, Working Paper series: CRCB-WP/2013:01 Version 2.0, Budapest, Hungary. Available on the Internet: http://www.crcb.eu/wp-content/uploads/2013/12/Fazekas-Toth-King_Corruption-manual-for-beginners_v2_2013.pdf

Fleming, M., Roman H.J., Farrel G. (2000), ‘The shadow economy', Journal of International Affairs, 53(2): 64-89.

Jeremy de Beer, Kun Fu, Sacha Wunsch-Vincent. (2013). The informal economy, innovation and intellectual property - concepts, metrics and policy consideration. WIPO Economics and statistics series. Available on the Internet: http://www.wipo.int/edocs/pubdocs/en/wipo pub econstat wp 10.pdf

Hyytinen, A., Lundberg, S., Toivanen, O. (2005). Favoritism in public procurement: evidence from Sweden. Available on the Internet: http://idei.fr/sites/default/files/medias/doc/conf/veol/toivanen.pdf

Krasny, A. (2014). Georgia Available $\quad$ on $\quad$ the $\quad$ Internet: https://www2.deloitte.com/content/dam/Deloitte/ua/Documents/public-sector/egovernment/Electronic\%20government\%20of\%20Georgia.pdf

Litina, A. Palivos, T. (2015). Corruption and tax evasion: reflections on Greek tradegy. Working paper 193, Bank of Greece. Available on the Internet: http://www.bankofgreece.gr/BogEkdoseis/Paper2015193.pdf

Loayza, N.V., Oviedo, A.M., Servén, L. (2005a). The Impact of regulation on growth and informality: Cross Country Evidence, World Bank, Policy Research Paper WPS3623, Washington, D.C. Available on the Internet: http://documents.worldbank.org/curated/en/212041468134383114/pdf/wps36230rev.pdf

Mkenda B.K., Aikaeli J. (2014). Informal Construction Employment, Earnings and Activities: A Boon or Bane for Tanzania? Tanzanian economic review Vol. 4 Nos. 1 \& 2. Available on the Internet: http://journals.udsm.ac.tz/index.php/ter/article/view/460/627

Naumov, A. (2014). Georgia E-experience for Belarus. Available on the Internet: http://e-gov.by/best-practices/elektronnyj-opyt-gruziidlya-belarusi.

Official website of Transparency International. Available on the Internet: https://www.transparency.org/.

Official website of Belarusian National Statistical Committee. Available on the Internet: http://www.belstat.gov.by

Official website of municipal procurements in Belarus. Available on the Internet: http://www.icetrade.by

Official website of the European Commission. Available on the Internet: https://ec.europa.eu/commission/index_en 
ENTREPRENEURSHIP AND SUSTAINABILITY ISSUES

ISSN 2345-0282 (online) http://jssidoi.org/jesi/

2017 Volume 5 Number 2 (December)

http://doi.org/10.9770/jesi.2017.5.2(8)

Putnis, J.T., Sauka, A. (2016). Shadow economy index for the Baltic countries 2009 - 2016. The Center for Sustainable Business at SSE Riga. - 47 p.

Putnis, J.T., Sauka, A. (2015). Measuring the shadow economy using company managers. Journal of Comparative Economics 43, pp. 471490.

Pelipas, I., Tochitskaya, I. (2016). Problems of corruption in the assessments of small and medium enterprises. Available on the Internet: http://www.research.by/webroot/delivery/files/dp2016r08.pdf

Procurement in construction, what has been changed since January 1, 2017. Available on the Internet: http://www.mas.by/ru/news_ru/view/zakupki-v-stroitelstve-chto-izmenilos-s-1-janvarja-2017-goda-852/

Preventing corruption in public procurements (2016). OECD Publishing. Available on the Internet: http://www.oecd.org/gov/ethics/Corruption-in-Public-Procurement-Brochure.pdf

Schneider, F., Enste D. (2000b), Shadow Economies: Size, Causes and Consequences, Journal of Economic Literature 38/1, 73-110.

Schneider, F. 2005. Shadow Economies around the World: What Do We Really Know? European Journal of Political Economy 21/4, 598642 .

Schneider, F., Williams C.C. (2013). The Shadow Economies. The Institute of Economic Affairs (UK), Available on the Internet: https://iea.org.uk/wp-content/uploads/2016/07/IEA\%20Shadow\%20Economy\%20web\%20rev\%207.6.13.pdf

Schneider, F. (eds.), (2011). Handbook on the Shadow Economy, Cheltenham (UK), Edward Elgar Publishing Company.

Zaiats, D. (2015). The authorities will strengthen the fight against the shadow economy [Electronic resource]. Available on the Internet: https://news.tut.by/economics/465337.html

\section{Aknowledgements}

This research was conducted in the framework of the project "Corporate engagement in fighting corruption and tax evasion”. The project is financed by the Nordic Council of Ministers.

Anastasiya LUZGINA is an Associate Professor at the Belarusian State University and Senior Researcher at the Belarusian Economic Research and Outreach Center. Anastasiya has work experience at the National Bank of the Republic of Belarus (2003-2007) and at the IMF Resident Representative office in Belarus as an economist (2007-2009). She has Belarusian PhD degree in Economics (2014). Anastasiya Luzgina also participated and successfully finished different economic courses and study programs, such as applied economic policy course at Joint Vienna Institute, exchange rate regulation course at the Study Center of the Central Bank of Switzerland, course at the IMF Institute in Washington and some other economic courses and seminars. Anastasiya Luzgina has more then 15 peer-reviewed publications. Main interests: monetary integration, macroeconomic development, social system transformation, FDI, problems of electronic government development, employment and income, development of FinTech market, currency and monetary policy, problems of corruption and tax evasion. She takes part in different economic conferences and seminars.

ORCID ID:

Register for an ORCID ID: https://orcid.org/register

Copyright (C) 2017 by author(s) and VsI Entrepreneurship and Sustainability Center

This work is licensed under the Creative Commons Attribution International License (CC BY).

http://creativecommons.org/licenses/by/4.0/

cC) (i) Open Access 